\title{
Calymperaceae, a new family to the bryological FLORA OF URUGUAY
}

\author{
Calymperaceae, una nueva familia para la flora briológica de \\ URUGUAY
}

Richard A. Cabral ${ }^{1}$, María S. Jimenez ${ }^{1}$ y yuillermo M. Suárez $z^{2,3 *}$ (iD

1. Instituto de Botánica del Nordeste (IBONE-CONICET-UNNE), Sargento Cabral 2131, Corrientes, Argentina.

2. Unidad Ejecutora Lillo, (CONICETFundación Miguel Lillo), Miguel Lillo 251, San Miguel de Tucumán, Tucumán, Argentina.

3. Facultad de Ciencias Naturales e Instituto Miguel Lillo, Universidad Nacional de Tucumán; Miguel Lillo 205, San Miguel de Tucumán, Tucumán, Argentina.

*suarezgm@csnat.unt.edu.ar

Citar este artículo CABRAL, R. A., M. S. JIMENEZ and G. M. SUÁREZ. 2020. Calymperaceae, a new family to the bryological flora of Uruguay. Bol. Soc. Argent. Bot. 55: 359-367.

DOI: https://doi. org/10.31055/1851.2372.v55. n3.28520
Recibido: 8 Mayo 2020

Aceptado: 30 Junio 2020

Publicado: 30 Septiembre 2020

Editor: Gabriel Bernardello (D)

ISSN versión impresa 0373-580X ISSN versión on-line 1851-2372

\section{SUMMARY}

Background and aims: The aim of this work was to increase the knowledge of the bryoflora of Uruguay based on the analysis of samples collected in Fortaleza Santa Teresa National Park.

M\&M: Specimens were collected, processed and analyzed morphologically using conventional techniques for bryophytes. Microscopic characters were observed and illustrated with light microscopy (LM) and scanning electron microscopy (SEM).

Results: Calymperaceae Kindb. are recorded for the first time to the country, represented by Syrrhopodon gaudichaudii Mont. This species is characterized by leaves strongly crispate when dry, and margins smooth to dentate at the apex.

Conclusions: A detailed description, illustrations with SEM and LM of S. gaudichaudii is here presented.

\section{KEY WORDS}

Acrocarpous, cancellinae, Fortaleza Santa Teresa National Park, Syrrhopodon gaudichaudii.

\section{RESUMEN}

Introducción y objetivos: El objetivo de este trabajo es contribuir al conocimiento de la flora de briófitos en Uruguay, por medio del estudio de colecciones realizadas en el Parque Nacional Fortaleza Santa Teresa.

M\&M: Las muestras se coleccionaron, procesaron y analizaron morfológicamente mediante técnicas convencionales para briófitas. Los caracteres microscópicos se observaron e ilustraron con microscopía óptica (LM) y microscopía electrónica de barrido (MEB).

Resultados: La familia Calymperaceae Kindb. se registra por primera vez en el país, representada por Syrrhopodon gaudichaudii Mont. Esta especie se caracteriza por las hojas crispadas cuando secas, con margen liso a dentado en el ápice.

Conclusiones: Se presenta una descripción detallada e ilustraciones en MO y MEB de S. gaudichaudii.

Palabras clave

Acrocárpicos, células cancelinas, Parque Nacional Fortaleza Santa Teresa, Syrrhopodon gaudichaudii.

\section{INTRODUCTION}

Calymperaceae are a pantropical family defined by the presence of costate leaves with a well-defined basal lamina formed from large, empty cells with thin, usually perforate walls (Ellis, 2016). According to several authors (Andrews, 1947; Magill, 1981; Ellis, 1985, 2016; La Farge et al., 2000; Fisher, 2007) this family is represented by taxa with leucobryoid leaves (Arthrocormus Dozy \& Molk., Exodictyon Cardot, Exostratum L.T.Ellis, and Leucophanes Brid.) and taxa with non-leucobryoid leaves (Calymperes Sw. ex F.Weber, Chameleion L.T.Ellis \& A.Eddy., Mitthyridium H.Rob., and Syrrhopodon Schwägr.). In the Neotropics, the most diverse of these genera are Syrrhopodon and Calymperes, with 31 and 16 species, respectively (Gradstein et al., 2001). 
Syrrhopodon was described in 1824 by Schwägrichen, and includes ca. 115 accepted species (O'Shea, 2001). It is mostly epiphytic on tree bases, trunks and branches, but also occasionally on soil or rocks (Reese, 1993). The genus commonly occurs in humid or semi-dry lowland forests, but its diversity decreases in montane forests above $3000 \mathrm{~m}$ asl (Gradstein et al., 2001). Diagnostic characters include: erect stems; leaves composed of a semi-sheathing, clasping, hyaline base that narrows distally into a lanceolate, ligulate or linear chlorophyllose limb; the costa is strong, percurrent to shortly-excurrent; cells in the chlorophyllose lamina are largely isodiametric, often papillose or spinose; hyaline cells forming the basal lamina are sub-rectangular, thin-walled, often porose, and a narrow marginal limbidium often extends from the leaf base to (or near to) the leaf apex (Reese, 1993; BFNA, 2007).

In America, Reese (1977, 1978, 1993) classified the species in two major groups, limbate and elimbate, based on the presence/absence in the leaves of a complete or incomplete margin of linear hyaline cells (most often stereids). Syrrhopodon gaudichaudii Mont. has limbate leaves, and can easily be distinguished from other limbate species. The hyaline basal part of the leaf is appressed to the stem, but when dry, the chlorophyllose leaf limb is unusually strongly crispate; the cancellinae in the leaf base are well developed; the limbate leaf margin is largely entire, but dentate at the leaf apex; acute teeth are also notable on the dorsal surface near the apex of the costa (Ellis, 2018). Although this taxon is known through the Neotropics from the southern United States to northern Argentina (Reese, 1993), there has been no record of $S$. gaudichaudii, or indeed the family Calymperaceae, in Uruguay (Matteri, 2004).

Among collections made by the authors in 2011 from the eastern part of Fortaleza Santa Teresa National Park (Uruguay), an unexplored area of this country, were samples identifiable as Syrrhopodon gaudichaudii. Therefore, the family Calymperaceae is known in Uruguay for the first time, represented by $S$. gaudichaudii. This finding, among others discovered through the last years by the authors (Ellis et al., 2011, 2012a, 2012b; Suárez \& Schiavone, 2013; Flores \& Suárez, 2014; Suárez et al., 2014, 2017; Jimenez et al., 2019), highlights the floristic singularity and the scarce knowledge of the bryophytic flora in the country. A detailed description of the species and illustration in SEM and LM is here presented.

\section{Material and Methods}

Samples collected were processed and deposited at CTES and LIL. The specimens were analyzed morphologically with conventional techniques for bryophytes and mounted in Hoyer's solution (Anderson, 1954). Microscopic characters were observed and illustrated with light microscopy (LM) Leica CME and scanning electron microscopy (SEM) JEOL 5800 LV. Characters illustrated using SEM were obtained from samples fixed in formaldehydeacetic-acid-alcohol-water (FAA), critical-point dried, mounted on double-sided tape and coated with goldpalladium. Spores were obtained from mature opened capsules, removed with FAA, mounted directly on aluminum stubs and subsequently coated with goldpalladium. Spores were described following Punt et al. (2007) and Brubaker et al. (1998). Samples were compared with identified collections preserved in CTES and LIL.

\section{Results}

\section{Taxonomic treatment}

Syrrhopodon gaudichaudii Mont. Annales des Sciences Naturelles; Botanique, sér. 2, 2: 376, 16 f. 3. 1834. TYPE: [Brazil], 'au pied des arbres, où il forme de beaux gazons, dans l'ile de Sainte-Catherine', [leg. Gaudichaud] '(.. in herb. Gaudich. n. 11)'. (LECTOTYPE selected by Ellis, Journal of Bryology 40(2), 137-142. 2018: BM; isolectotypes BM, G, P, NY). Figs. 1-5.

For a complete synonymy see Orban (1981); Reese (1983) and Ellis (2018).

Plants in dense tufts, greenish-gray to darkgreen; stems $0.6-(2.0)-3 \mathrm{~cm}$ long, highly branched, $125 \mu \mathrm{m}$ diameter, central strand absent, epidermis bistratose. Leaves loosely to tightly crispate when dry, uncurled to patent when wet, 2-3 mm long, lanceolate to ligulate-acuminate, with a hyaline base narrowing into linear-ligulate, broadly channelled chlorophyllose limb; margins entire at base, toothed at the apex, limbidium 
R. A. Cabral et al. - Calymperaceae, new to Uruguay

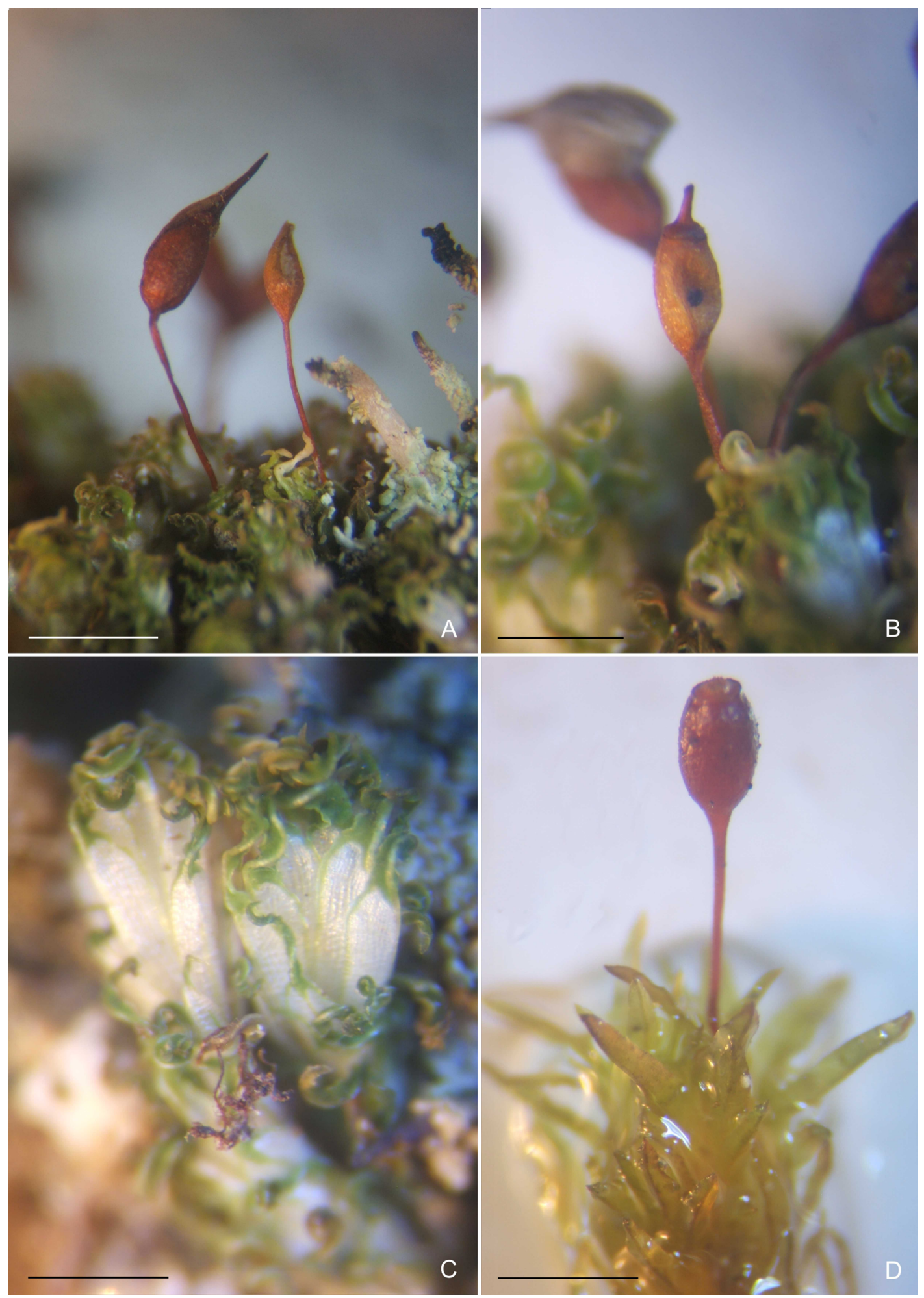

Fig. 1. A. Detail of capsule with calyptra. B. Detail of capsule without calyptra. C. Detail of the gametophyte when dry. D. Detail of the plant when wet (Suárez 1067, 1128; CTES). Scale bars: $0.1 \mathrm{~mm}$. 
Bol. Soc. Argent. Bot. 55 (3) 2020

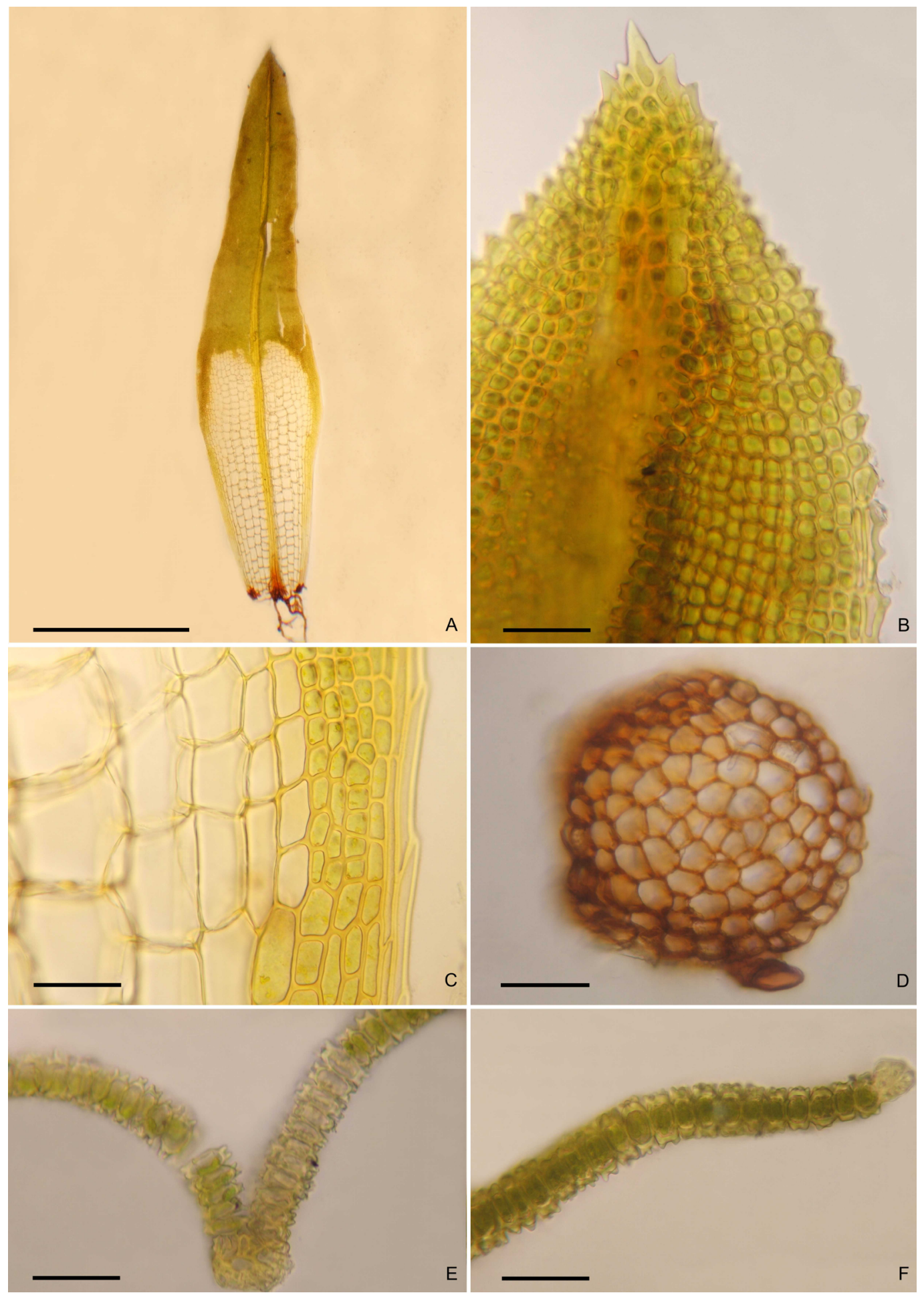

Fig. 2. A. Leaf. B. Apex of leaf. C. Base of leaf with well-developed cancellinae. D. Stem in transverse section. E. Costa in transverse section. F. Detail of leaf margin with 3-4 rows of hyaline cells (Suárez 1067, 1128; CTES). Scale bars: $50 \mu \mathrm{m}$. 
R. A. Cabral et al. - Calymperaceae, new to Uruguay

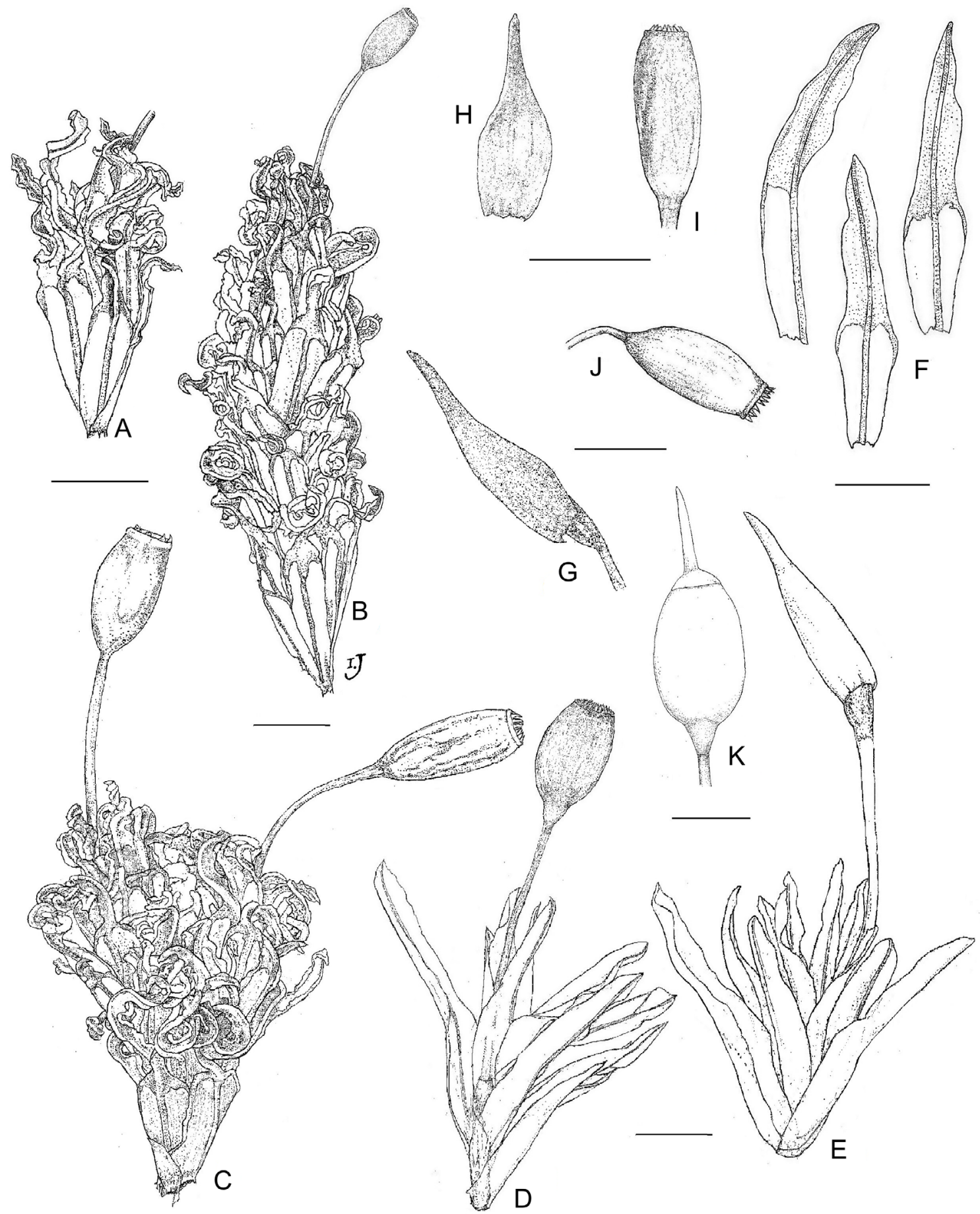

Fig. 3. A, B, C. Habit of the plant when dry. D, E. Habit of the plant when wet. F. Leaves. G. Sporophyte with calyptra. H. Detail of the calyptra. I, J. Deoperculate capsules. K. Operculate capsule (Suárez 1067, 1128; CTES). Scale bars: $1 \mathrm{~mm}$. 


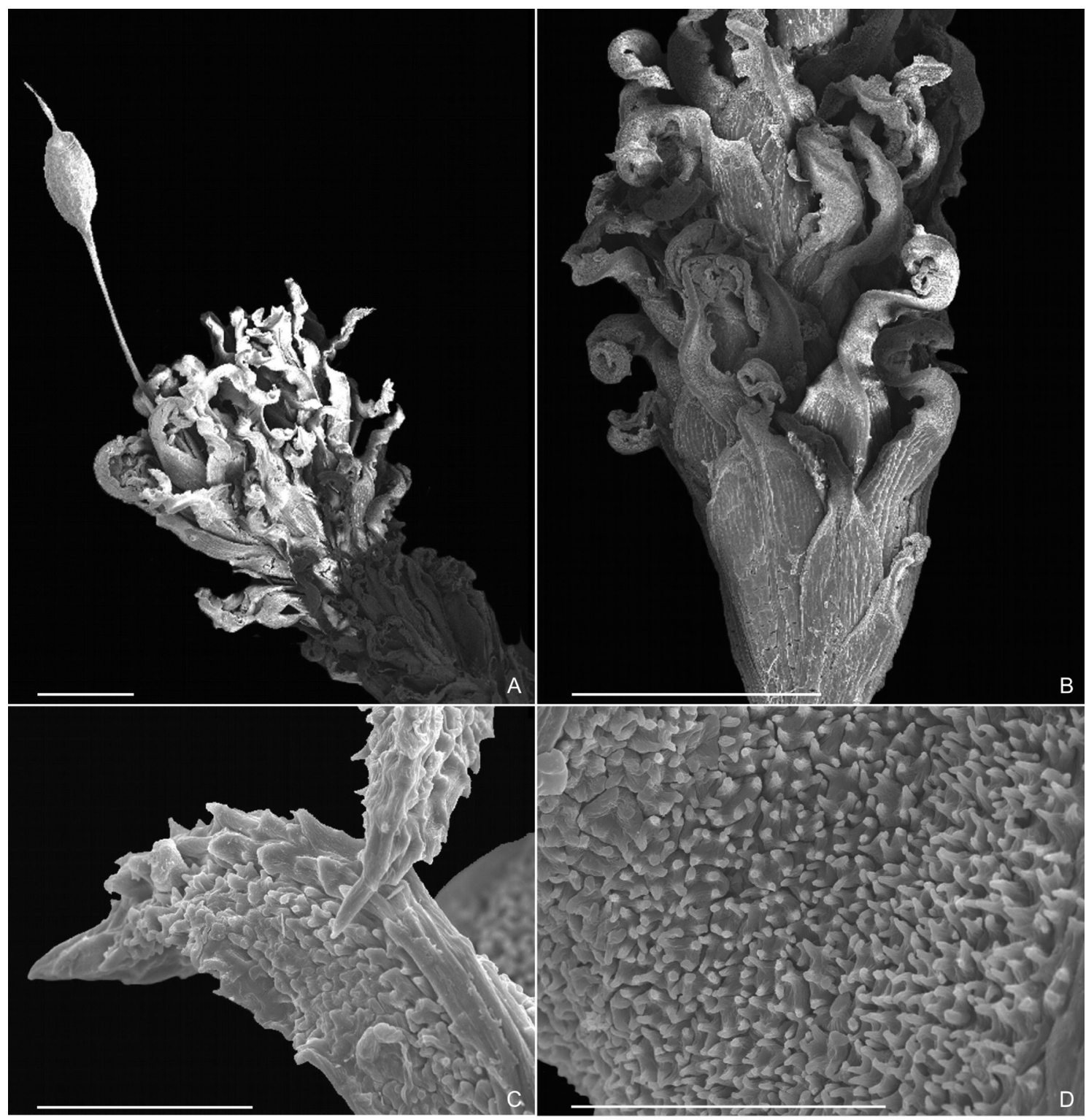

Fig. 4. Gametophyte in SEM. A. Complete plant. B. Detail of the curled limb of the leaf. C. Detail of the toothed costae and margin at the apex of the leaf. D. Pluripapillose laminal cells at the median part of the chlorophyllose limb (Suárez 1067, 1128; CTES). Scale bars: A-B: 1 mm; C-D: 50 mm.

well developed, with 4 rows of elongate, hyaline cells at base, becoming 2 rows at the apex; apex obtuse, often ending in a large apical tooth; costae percurrent, dorsal surface toothed at the apex; cancellinae distinct, cells 21.5(-52.5-)99.6 $\times 16.6(-30.1-) 48.1 \mu \mathrm{m}$, rectangular, elongate towards the margin, median and upper laminal cells $6.6(-23.4-) 58.1 \times 8.3(-15.9-) 36.5 \mu \mathrm{m}$, quadrate to isodiametric, pluripapillose (4-5 papillae per lumen). Setae 3.5-4 mm long, red. Capsules cylindrical, 1-1.5 $\mathrm{mm}$ long, brown. Peristome teeth 101-124.5 $\mu \mathrm{m}$, papillose. Operculum conic- 


\section{R. A. Cabral et al. - Calymperaceae, new to Uruguay}
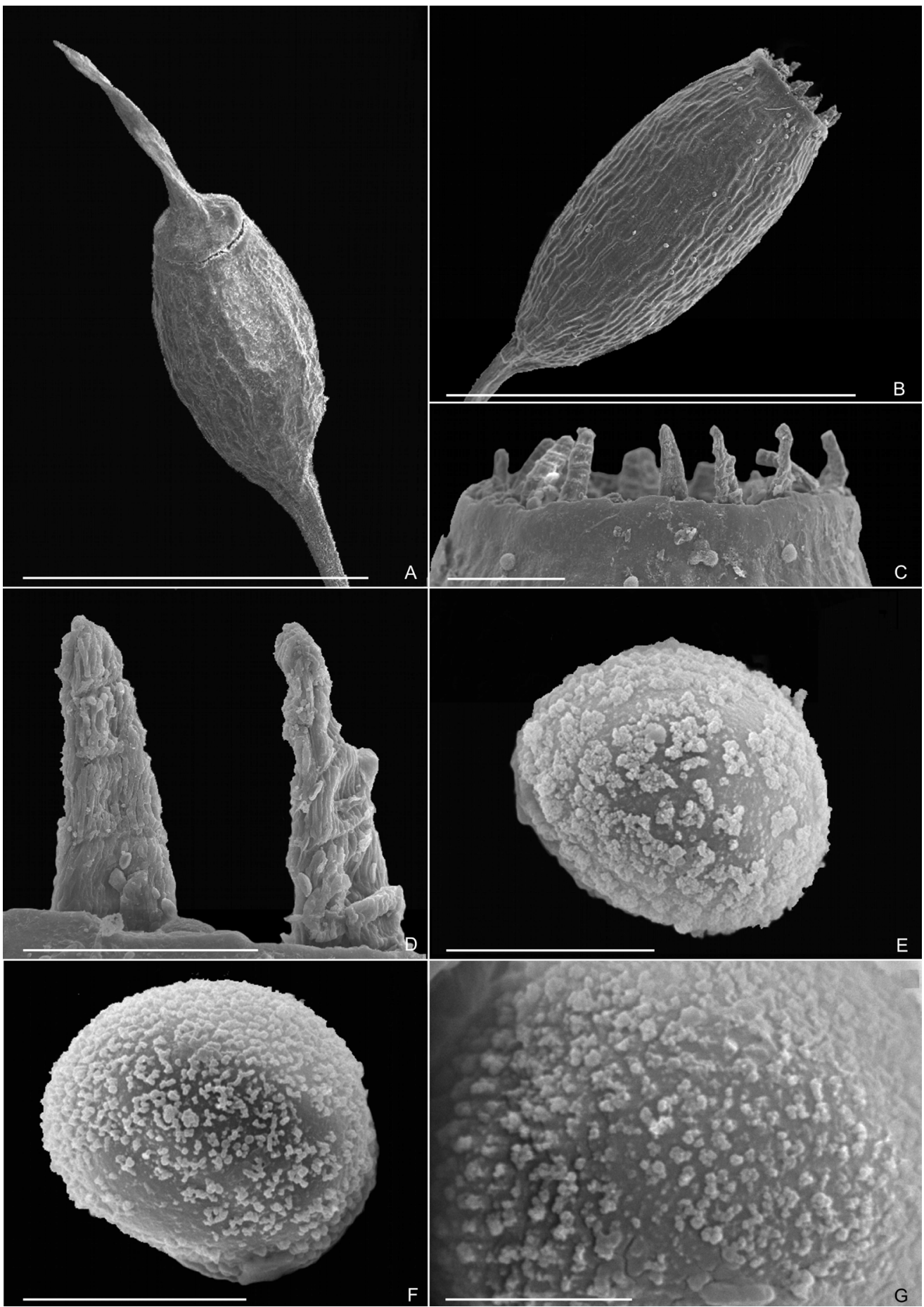

Fig. 5. Sporophyte in SEM. A. Operculate capsule. B. Deoperculate capsule. C. Peristome. D. Detail of the peristome teeth. E. Spore in distal view. F. Spore in equatorial view. G. Close-up of the gemmate

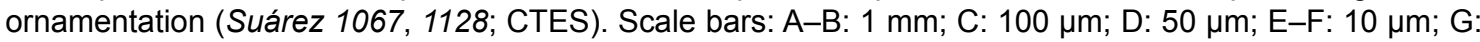
$5 \mu \mathrm{m}$. 
rostrate. Calyptra cucullate. Spores spheroidal, in equatorial view plane-convex, 13-15(-19.9) $\mu \mathrm{m}$, yellow, finely gemmate, gemmae heterogenously dispersed at surface.

Distribution and habitat. It has been recorded from continental Africa, the East African Islands and eastern Oceania. In America its range of distribution extends to the southeastern United States, Mexico, Costa Rica, Panama, Jamaica, Cuba, Puerto Rico, Guadalupe, Colombia, Venezuela, Suriname, Ecuador, Bolivia, south of Brazil and northern Argentina (Reese, 1978, 1993; Matteri, 2003). It is recorded here for the first time from Uruguay. This species forms cushions closely packed on tree trunks, decaying logs, soil and rocks (Ellis, 2018).

Comments. Syrrhopodon gaudichaudii is easily recognized in the field by its whitish leaves due to the presence of well-developed cancellinae, the base of leaves appressed to the stem, and the strongly curled limb when dry.

Specimens examined. URUGUAY. Rocha: Parque Nacional Fortaleza Santa Teresa, $34^{\circ} 00^{\prime} 7.87^{\prime \prime} \mathrm{S}, 53^{\circ} 33^{\prime} 21.63^{\prime \prime} \mathrm{W}, 33 \mathrm{~m} \mathrm{snm}$, sobre roca, 03/01/2011, G. Suárez 1067 (CTES, LIL); 10/01/2011, G. Suárez 1128 (CTES, LIL). ARGENTINA. Corrientes: Reserva Natural Privada Paraje Tres Cerros, Cerro Nazareno, en grietas de las rocas, abundante, húmedo y sombrío, 2906'32.79' 'S, 56 $55^{\circ} 5^{\prime} 55.82^{\prime \prime} \mathrm{W}, 171 \mathrm{~m}$ snm, 2/12/12, Jimenez et al. 449 (CTES).

\section{AUTHORS CONTRIBUTION}

RC determined and described the samples; MSJ illustrated in SEM and LM, GMS collected and confirmed the determination, all authors have worked simultaneously on the manuscript.

\section{ACKNOWLEDgMENTS}

The authors thank L.T. Ellis for constructive comments on an earlier version of this manuscript. This research was supported by SGCyT (UNNE), CONICET, PICT 2016-0810 and, PIUNT G631.

\section{Bibliography}

ANDERSON, L. 1954. Hoyer's solution as a rapid permanent mounting medium for bryologists. Bryologist 57: 242-244. https://doi.org/10.2307/3240091

ANDREWS, A. L. 1947. Taxonomic notes VI. The Leucobryaceae. Bryologist 50: 319-326.

BFNA. 2007. Calymperaceae Kindberg. In Flora of North America Editorial Committee (Ed.). (1993). Flora of North America North of Mexico: Bryophyta (Vol. 27). Part 1, 654-657. Oxford University Press, New York, Oxford.

BRUBAKER, L. B., P. M. ANDERSON, B. M. MURRAY, \& D. KOON. 1998. A palynological investigation of true-moss (Bryidae) spores: Morphology and occurrence in modern and late Quaternary lake sediments of Alaska. Canad. J. Bot. 76: 2145-2157. https://doi.org/10.1139/b98-192

ELLIS, L. T. 1985. A taxonomic revision of Exodictyon Card. (Musci: Calymperaceae). Lindbergia 11:9-37.

ELLIS L. T. 2016. Syrrhopodon Schwägr. (Calymperaceae, Musci) in India and adjacent regions, J. Bryol. 38: 1-27. https://doi.org/10.1179/1743282015Y.0000000024

ELLIS, L. T. 2018. Taxonomic and nomenclatural notes on Syrrhopodon gaudichaudii Mont. (Calymperaceae) and S. hawaiicus Müll.Hal. J. Bryol. 40: 137-142. https://doi.org/10.1080/03736687.2018.1447835

ELlis, L. T., A. K. ASTHANA, V. SAHU, A. SRIVASTAVA, H. BEDNAREK-OCHYRA, R. OCHYRA, J. CHLACHULA, M. T. COLOTTI, M. M. SCHIAVONE, Z. HRADILEK, M. S. JIMENEZ, H. KLAMA, M. LEBOUVIER, R. NATCHEVA, T. PÓCS, R. D. PORLEY, C. SÉRGIO, M. SIM-SIM, V. R. SMITH, L. SÖDERSTRÖM, S. STEFǍNUT, G. M. SUÁREZ \& J. VÁŇA. 2011. New national and regional bryophyte records, 28. J. Bryol. 33: 237-247.

https://doi.org/10.1179/1743282011Y.0000000022

ELLIS, L. T., A. ALEGRO, H. BEDNAREK-OCHYRA, R. OCHYRA, A. BERGAMINI, A. COGONI, P. ERZBERGER, P. GÓRSKI, N. GREMMEN, H. HESPANHOL, C. VIEIRA, L. E. KURBATOVA, M. LEBOUVIER, A. MARTINČIČ, A. K. ASTHANA, R. GUPTA, V. NATH, R. NATCHEVA, A. GANEVA, T. ÖZDEMIR, N. BATAN, V. PLÁŠEK, R. D. PORLEY, M. RANDIĆ, J. SAWICKI, W. SCHRODER, C. SÉRGIO, V. R. SMITH, P. SOLLMAN, S. STEFǍNUT, C. R. STEVENSON, 


\section{R. A. Cabral et al. - Calymperaceae, new to Uruguay}

G. M. SUÁREZ, B. SURINA, G. UYAR \& Z. MODRIČ SURINA. 2012a. New national and regional bryophyte records, 31. J. Bryol. 34: 123-134. https://doi.org/10.1179/1743282012Y.0000000009

ELLIS, L. T., H. BEDNAREK-OCHYRA, R. OCHYRA, B. CYKOWSKA, M. V. DULIN,, T. EZER, R. KARA, J. R. FLORES, G. M. SUÁREZ, C. GARCIA, A. MARTINS, C. SÉRGIO, R. GARILLETI, M. KIRMACI, E. AGCAGIL, L.E. KURBATOVA, M. LEBOUVIER, B. PAPP, E. SZURDOKI, D. A. PHILIPPOV, V. PLÁSĔK, T. PÓCS, M. SABOVLJEVIĆ, J. SAWICKI, M. SIM-SIM, P. SZÜCS, A. BIDLÓ, J. VÁŇA, B. VIGALONDO, F. LARA, I. DRAPER, V. M. VIRCHENKO \& G. J. WOLSKI. 2012b. New national and regional bryophyte records 33. J. Bryol. 34: 281-291. https://doi.org/10.1179/1743282012Y.0000000030

FISHER, K. M., D. P. WALL, K. L. YIP \& B. D. MISHLER. 2007. Phylogeny of the Calymperaceae with a rank-free systematic treatment. Bryologist 110: 46-73.

https://doi.org/10.1639/0007-2745(2007)110[46:POT CWA]2.0.CO;2

FLORES, J. R. \& G. M. SUÁREZ. 2014. Redescription of the genus Cryphidium (Cryphaeaceae, Bryophyta), with notes on its taxonomy. Bol. Soc. Argent. Bot. 49: 195-199.

GRADSTEIN, S. R., S. CHURCHILL \& N. SALAZARALLEN. 2001. Guide to the Bryophytes of Tropical America. Mem. New York Bot. Gard. 86: 1-577.

JIMENEZ S., G. M. SUÁREZ \& R. ZANDER. 2019. Novelties on Tortella (Müll.Hal.) Limpr. (Pottiaceae) from South America. Cryptog. Bryol. 40: 40-50. https://doi.org/10.5252/cryptogamiebryologie2019v40a8

LA FARGE, C., B. D. MISHLER, J. A. WHEELER, D. P. WALL, K. JOHANNES, S. SCHAFFER \& A. J. SHAW. 2000. Phylogenetic relationships within the haplolepideous mosses. Bryologist 103: 257-276. https://doi.org/10.1639/00072745(2000)103[0257:PRWTHM]2.0.CO;2
MAGILL, R. E. 1981. Flora of Southern Africa. Bryophyta. Part 1. Mosses. Fascicle 1 SphagnaceaeGrimmiaceae. Botanical Research Institute, Pretoria. MATTERI, C. M. 2003. Los musgos (Bryophyta) de Argentina. Trop. Bryol. 24: 33-100.

MATTERI, C. M. 2004. The mosses (Bryophyta) of Uruguay, their synonymy and distribution. Cryptog. Bryol. 25: 147-167.

MOHAMED H. \& W. D. REESE. 1985. Syrrhopodon (Musci: Calymperaceae) in Malaysia and adjacent regions. Bryologist 88: 223-254.

https://doi.org/10.2307/3243033

ORBAN, S. 1981. Studies on African Calymperaceae. III. Conspectus of the African species of Syrrhopodon Schwaegr. Acta Biol. Acad. Sci. Hung. 27: 169-177.

O'SHEA, B. J. 2001. A synopsis of the non-leucobryoid Calymperaceae (Musci). Trop. Bryol. Res. Rep. 2: 1-93.

PUNT W., P. P. HOEN, S. BLACKMORE, S. NILSSON \& A. LE THOMAS. 2007. Glossary of pollen and spore terminology, Rev. Palaeobot. Palynol. 143: 1-81. https://doi.org/10.1016/j.revpalbo.2006.06.008

REESE, W. D. 1977. The genus Syrrhopodon in the Americas. I. The elimbate species. Bryologist 80: 2-31. https://doi.org/10.2307/3242508

REESE, W. D. 1978. The genus Syrrhopodon in the Americas. II. The limbate species. Bryologist 81: 189-225. https://doi.org/10.2307/3242184

REESE, W. D. 1993. Calymperaceae. Flora Neotropica Monograph 58: 1-101. The New York Botanical Garden, New York.

SUÁREZ, G. M., \& M. M. SCHIAVONE. 2013. Contributions to the moss flora of Uruguay: the genus Pohlia (Bryophyta, Bryales), a new record. Darwiniana 1: 61-66

SUÁREZ G. M., M. M. SCHIAVONE \& T. COLOTTI. 2014. The genus Holomitrium (Dicranaceae, Bryophyta), new record in Argentina and Uruguay. Bol. Soc. Argent. Bot. 49: 457-461.

SUÁREZ G. M., M. S. JIMENEZ \& J. R. FLORES. 2017. The genus Bartramia Hedw. (Bartramiaceae, Bryophyta) in Uruguay. Gayana, Bot. 74: 123-127. 
